\title{
Xenophobic violence and criminality in the KwaZulu-Natal townships
}

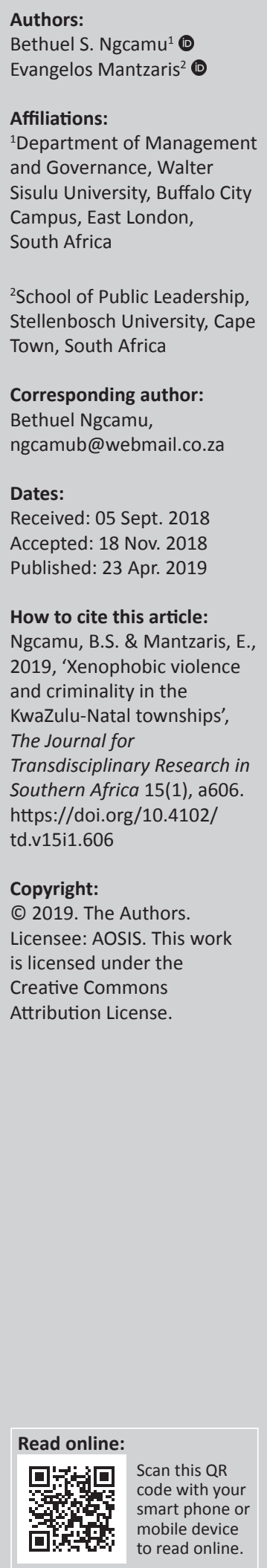

This study's focus on the xenophobic violence in South Africa is topical, mostly concentrating on the economic competition between foreign nationals and local people as a root cause. Whilst the South African government's record of poor governance has led to a high crime rate, poor service delivery, corruption and poorly implemented and enforced legislations have been overlooked and disassociated with xenophobia. The current study explores other forces that have triggered the xenophobic violence in South Africa in 2015 with a clear focus on the province of KwaZulu-Natal. The study aims to ascertain some of the causes and dimensions of the xenophobic violence and the government's inability to detect and respond to such a catastrophe in KwaZulu-Natal. The research methodology chosen was interpretivism, utilising qualitative in-depth interviews. Seventeen informants, comprised of community activists, non-governmental organisations and government officials, including the South African Police Service, were interviewed. Four major themes that triggered and influenced xenophobia emerged in this study. Firstly, there is economic competition amongst foreign nationals who use local gangs to attack their competitors, as well as competition between foreigners and local business owners. Secondly, the study established an association between xenophobia and criminal business, where both victims and perpetrators compete over turf and skills in committing crimes. Thirdly, the study noted the inability of the state to employ risk-reduction to prevent and mitigate the impacts of xenophobia. Fourthly, the state apparatus's failed to detect, prevent or mitigate the impact and respond timeously. A number of themes and issues untouched in previous research surfaced. This study necessitates the need for municipalities to develop or review by-laws on economic development in the townships and in the informal settlements by regulating informal businesses. The research study will further encourage the government to apply effective, efficient and appropriate crime-intelligence strategies that can detect or combat any sign of xenophobia in all sectors of society. The study will contribute to the conceptual and theoretical empirical developments and realities regarding the issues, as well as the policy, as most studies published on xenophobic violence have concentrated on the economic dimension, to the exclusion of other underlying causes.

Keywords: Xenophobia; competition; intelligence; illegal immigrants; gangsterism; township.

\section{Introduction}

South Africa has experienced violence against African foreigners since 2008, and it has become an almost chronic problem. The uncontrolled influx of migrants has been categorised over the years as legal, documented, illegal or undocumented (Bekker et al. 2008:9). On occasion, such realities have led to what has been called 'xenophobic' or 'Afro-phobic' violence. On 30 March 2015, attacks on foreign nationals started in Isipingo, outside Durban, and later spread to other areas. Mainly, these attacks were directed at African immigrants and their businesses, allegedly sparked by a labour dispute over the employment of immigrants at Jeena Supermarket in Isipingo. Later, South African families who were landlords to immigrants were also targeted.

Goddey (2017) attributes the causes of the xenophobic violence in Africa to numerous factors including civil wars and communal crises, poverty and unemployment, cultural and biological differences, contestations on religion, and criminal activities including human trafficking. The author further mentions the discrimination faced by foreigners from state security agencies, provocative statements by leaders and divisive media reporting as root causes. There has been a plethora of authors who have attributed such events to the dislike or hatred of foreigners by indigenous people (Akinola 2014; Ramphele 2008), cultural and biological differences (Nyamnjoh 2006), stereotypes and intergroup anxiety (Mothibi, Roelefse \& Tshivhase 2015) and scapegoating for social ills in a foreign country. Tafira (2011) terms it a culturally-based racism exacerbated by 
ethnicity, speech patterns and accents, economic and social inequalities, cultural and ethnic differences, and social and territorial origins.

It has been said that the continuous scramble of immigrants into South Africa is because they are running away from their own impoverished countries (Oucho 2006) or are in search of economic opportunities at the mines and commercial farms (Crush et al. 2006) in South Africa. Research studies of the phenomenon in the country have been confined to the economic dimension as the main reason behind the xenophobic violence. In this analysis, South Africans have been described as the perpetrators, and the foreigners as the victims.

In view of this, the current study attempts to gain insight into different stakeholders' understanding of different dimensions, such as the existence of 'a third force' as an explanation for the xenophobic violence, and to assess the government's capability to detect and respond timeously to such violence.

The study by Tsheola and Segage (2015) interpreting and 'theorising' xenophobia as the 'new racism' rejected the belief that the 'new South African identity' expresses a 'new racism'. A regression analysis performed by Ruedin (2018) of the South African Social Attitudes Survey (HSRC 2013) displayed clear patterns indicating that people in vulnerable social and economic positions and people with less contact with foreigners are xenophobic. A study by Tshishonga (2015) exploring the impact of xenophobic attacks on the informal economy during the 2015 violence in the Durban Central Business District (CBD) revealed that the events had detrimental effects for both non-South African and local traders as those visiting the vicinity mainly depended on the services of informal businesses.

A number of authors (Mothibi et al. 2015; Ntshishonga 2015) posit that fear was evident in the Louis Trichardt and Durban CBDs during the 2008 and 2015 xenophobic violence. Against the backdrop articulated above, this study attempts to achieve the following objectives:

- to ascertain civil society's perception with regards to 'a third force' as an explanation for the xenophobic violence

- to assess the adequacy of the government's mechanisms for understanding, detecting, investigating and responding to xenophobia

- to investigate and uncover new dynamics and realities underlying the roots and actions related to xenophobic violence.

The utilisation of the case study approach and research design, based on interpretation of in-depth interviews as a data collection method, is believed to be the foundation of a new understanding of the phenomenon at local level (Saunders, Lewis \& Thornhill 2007:103). Its exploratory element was based on in-depth, face-to-face, qualitative interviews (Blumberg, Cooper \& Schindler 2005), where the data categories, based 'lived experience', were dissected (Charmaz 1990:1162).

\section{Conceptual framework}

There are a number of interpretations and perceptions of the meaning and causes of xenophobia. McDonald and Jacobs (2005) and Shisana (2008) refer to it as 'a deep dislike of foreigners'. Crush and Ramachandran (2009) and Crowther (1995) describe it as 'strange or foreign and phobia'. The xenophobic violence of 2008 was regarded by Everatt (2011:10) as caused by a combination of sociopolitical conditions, whilst Crush (2008) has described what he calls 'anti-foreigner attitudes' as 'widespread and vitriolic'. Crush (2009:6) states that xenophobia is rooted in discriminatory practices emanating from negative perceptions about foreigners based on their nationality. Numerous researchers have referred to xenophobia as aggressive (Crush 2009:6), tension-based acts of violence (Hook \& Eagle 2002:170) and with the potential to cause bodily harm and damage (Harris 2002:170).

However, in the South African context, xenophobia may denote many things but it is mainly linked to criminal activity, which this study is partly investigating. A number of commentators define the phenomenon of crime as criminal offences motivated by hate and by the victim's group identity (Hall 2013:2), an intentional illegal act against a foreigner that is based on prejudice of the perpetrators against the perceived or real status of the victim (Craig 2002:86). Furthermore, some researchers define such violence as the result of foreigners being perceived as people of no value (Wolfe \& Copeland 1994:201). It has been assumed that social and political factors motivate such acts (Sheffield 1995:438), which in most cases are violent and discriminatory against marginalised and stigmatised groups (Perry 2001:10).

The present study takes into account the aforementioned interpretations and perceived causes of xenophobia and their relationship to criminality. However, it is believed that the underlying causes and influences of such violence have not yet been interrogated deeply and comprehensively by researchers in the townships or peri-urban areas where it is prevalent. Hence, this study attempts to fill this void and to unravel the core causes by targeting the wide array of 'foot soldiers', including civil society groups and government decisionmakers, who are directly affected by this catastrophe.

\section{Theoretical framework}

The scapegoating theory informs this study. It is a sociological theory that dissects aspects of prejudice in a period of change and social transition (Allport 1961). The author assumes that prejudice, driven by frustrations, lead to prejudice, mainly from marginalised local groups who identify foreigners as scapegoats. People displace their frustration onto convenient targets, thereby obscuring the actual causes of their anxiety. Hostile attitudes are formed in relation to unmet promises and limited resources, such as housing, education, healthcare and employment, coupled with high expectations during transition (Morris 1998; Tshitereke 1999). These are ideal circumstances for xenophobic acts to increase through the creation of a 'frustration scapegoat', who is perceived as the 
key reason for the local population's continuous poverty and deprivation (Tshitereke 1999:4).

This is supported by South Africa's xenophobic violence in 2008, which claimed 60 lives. In addition, 700 were wounded, dozens of foreigners were raped and more than 100000 were displaced. A third of those were South Africans who were considered to have been married to foreigners (Landau 2012:1). The researcher argues that the South African government denied the 2008 cataclysm, blaming it on the criminal element, opposition and sinister forces, with the Minister of Intelligence blaming criminals and foreigners for instigating the xenophobic violence. According to Landau (2012:2), community leaders, business associations and gangsters attacked and killed shopkeepers. The author opines that the xenophobic violence was caused by anger and resentment, the essence of overzealous citizenship and an anti-outsider sentiment by South Africans.

Meanwhile, Neocosmos (2010:1) posits that xenophobia is directed against Africans, with Mozambicans and Nigerians as the key targets because they are the key perpetrators of illegal immigration and drug dealing according to the media. He contends that foreigners who have reached South Africa for economic or political reasons are considered to be involved in acts of crime. This means that the perception is created that all the survival activities of foreigners are criminal. Such discrimination is aggravated by the economic and social crisis facing the country.

Neocosmos (2010:4) describes xenophobic attacks in South Africa as being associated with the country's transition to democracy and the frustrations of the local population; Morris (1998) and Tshitereke (1999) associate xenophobia with South Africa's historical exclusion from the rest of the African continent; and Morris (1998) with South Africans' intolerance towards strangers. Neocosmos (2010:15) outlines four theoretical positions on xenophobia: firstly, xenophobia excludes foreigners from communities; secondly, the process associated with exclusion is political, with the central role played by the state; thirdly, xenophobia is founded on the exclusion of foreigners from duties and citizenship; and finally, xenophobia is the result of a relationship between popular and state politics.

Neocosmos (2010:18) contends that xenophobia cannot be framed only on scarce resources, social change and competition but that it also revolves around the populardemocratic politics. The author developed a schematic theory that forms the basis of the understanding of xenophobia, which includes the division of labour that emanates from the realities of the political economy within the context of global capitalist and imperialist forces (migration). Neocosmos (2010:19) further mentions the process of state interpellation discourse as belonging to a nationality, ethnic and tribal groups, and gender. Finally, the author discusses the mediation of politics, which includes silence or voice, as well as popular politics. This study is guided by the theories articulated as it attempts to investigate the positions of these theories at a local level, where xenophobia occurs.

\section{Causes and dimensions of xenophobic violence}

Wimmer (1997) coined three theories that attempt to identify the causes of xenophobic violence. These are power theory, cultural-symbolic theory and phenomenology. The power theory stems from the belief that people's insecurities in the face of real or imagined 'threats' lead them to resentment and hatred and that violence stems from a competition between immigrants and locals (Nyamnjoh 2006). The cultural-symbolic theory is based on the belief that animosity is not a result of economic competition between local and foreign groups, whilst phenomenology articulates the position that such violence emanates from the state's reassurance to its nationals and to its boundaries. It is not a fight about scarce jobs but an outcome of a cultural clash.

According to Fungurai (2015) and Soyombo (2008), the economic theory attributes xenophobic violence to poverty and unemployment (especially amongst the youth), which leads the citizens of a country to become xenophobic. Xenophobic violence has been associated with a multiplicity of causes, including jealousy on the part of locals in respect of job opportunities, foreigners agreeing to lower salaries and foreign business successes (Clark 2011:5; Khosa \& Malitani 2014), foreigners' attraction to local girls as they can afford to spoil them (Dodson \& Oelofse 2002:134; Mnyaka 2003), encouragement of prostitution (Nkealah 2011:125) and foreigners as cheap labourers who 'steal' jobs from the locals (Nyamnjoh 2006:2; Steinberg 2010).

A research study conducted by Charman and Piper (2012) in Delft, an African township in Cape Town, surveyed 100 spaza (small, informal shop) owners and different key stakeholders, including the police, and found that such violence is not driven by anti-foreigner sentiment. The findings of the study revealed that the majority of spaza shopkeepers resented the advent of Somalian businesses, but consumers remained indifferent as they preferred the lower prices. The study found that 'violent entrepreneurship' rather than xenophobic violence was prevalent in Delft, which was exacerbated by business competition driven by a group of ruthless businesspeople, high crime levels and an association between business profitability and the protection offered by a powerful landlord. Moreover, those foreign shopkeepers who aligned themselves with gangsters and street committee leaders were most vulnerable to such violence. Charman and Piper (2012) espoused the belief that local shopkeepers whose businesses had suffered because of foreign competition had become both hostile and bitter with foreign competition. A number of authors have perceived xenophobic violence as triggered by the struggle to access resources, including low-cost housing, employment and business opportunities in the informal sector (Hadland 2008), as well as price competition and the demise of local establishments (Charman, Petersen \& Piper 2012; Mamabolo 2015). 
Numerous researchers have associated xenophobia with nationalism and nation-building (Neocosmos 2011), as well as with defensiveness, protectionism, criminal threat and diseases (Crush 2009). Such a position leads to the belief that the 2008 xenophobic violence was instigated and perpetrated mostly by poor, young South African men targeting properties and businesses of foreign African nationals (Bekker 2008:4-5). A desktop study analysing the trends of the xenophobia and violence in 2008 by Bekker et al. (2008) concluded that government officials were just reacting to attacks and disputed that the violence was of a xenophobic nature, that the attacks were perpetrated by criminals and that a 'third force' was responsible. Dodson (2010:1) believes that a democratic, human rights-based migration policy in South Africa is extraordinarily difficult.

In fact, research has shown that, nationally, $48 \%$ of the country's citizens believe that foreigners are a 'criminal threat' (Crush \& Williams 2003). Leggett's (2003:52) research findings showed that $63 \%$ of the respondents living in Johannesburg thought that it was 'foreigners' who had been committing most of the crime in the inner city. Landau and Jacobsen (2004:45) showed that there is a strong belief amongst $70 \%$ of Johannesburg's respondents that there has been a continuous increase of crime in the city primarily because of the 'foreign invasion'. The paucity of published studies in South Africa using a case study design makes the present study unique, as the province of KwaZulu-Natal was used. Parts of the province faced such events in 2015 and beyond. The majority of the studies conducted, as presented, show that such violence is motivated by economic competition without the utilisation of the voice of community activists, civil society groups or government officials to buttress such claims and beliefs.

Landau, Keogh and Singh (2005:2) reported that there is 'strong evidence' that foreigners who live or work in South Africa face discrimination at the hands of government officials, including the police and the country's citizens, as well as organisations entrusted with the management of their deportation and detention. The government's highest political leadership have declared the situation as an 'emergency', but a number of attempts to respond have not been adequate, as the so-called third force or 'criminal' elements predominate (Monson 2012:455). This has been supported by Desai (2008), who claimed that following the May 2008 attacks, a powerful xenophobic culture was created. The state organs were geared towards hounding African immigrants and the media engaged in stigmatisation and stereotyping, whilst in many townships African immigrants lived under the threat of scapegoating that carried within it the use of violence (Desai 2008:6). Furthermore, a plethora of derogatory names, characterised by stigmatisation and stereotypes and referring to immigrants, have been used by the print media, which has had an influence on the human behaviour of groups of foreign Africans. This study is informed by the perspectives presented, but it hopes to bring new realities to the fore by investigating and dissecting existing theories and perceptions. It hopes to dig deeper in an effort to discover reliable underlying causes and dimensions that fuel this violence.

Table 1 identifies the causes and dimensions of the xenophobic violence evident in existing literature.

Table 1 describes, in a condensed form, the real or perceived causes and dimensions of the xenophobic violence already evident in the existing literature. It can be gauged that most of these positions explicitly suggest that the causes or dimensions of such violence are basically rooted in economic competition between the South African people and 'African foreign nationals'. This economic competition includes foreigners being preferred for job opportunities and used as cheap labour by industries, and consumers' preference for their low prices. Moreover, the causal relationship between the xenophobic violence and other dimensions, including police incompetence and crime, is scant as compared to the economic competition.

\section{Research design and methodology}

The case study is based on the interpretative perspective and founded on the deep knowledge of a variety of different stakeholders with direct involvement in the situation. The study utilised an exploratory element where in-depth, face-to-face, unstructured interviews with a carefully selected, purposive sample were the core of the inquiry that included senior government officials in all tiers of government, leaders of civil

TABLE 1: The causes and dimensions of the xenophobic violence evident in existing literature.

\begin{tabular}{lc}
\hline Authors & Causes and dimensions of the xenophobic violence \\
\hline Economic dimensions & Economic competition \\
Charman and Pine (2012); Goddey (2017); Steenkamp (2009); Tafira (2011:114); Mamabolo (2015); Mothibi et al. (2015); & Job opportunities \\
Wimmer (1997) & Poverty and unemployment \\
Khosa and Kalatanyi (2014); Nyamnjoh (2006); Steinberg (2010); Hadland (2008); Mamabolo (2015); Nkealah (2011); & Cheap labour \\
Tshishonga (2015) & Consumers' preference for lower prices \\
Fungurai (2015); Mamabolo (2015); Nkealah (2011); Soyombo (2008) & Attracting local girls \\
Charman and Pine (2012); Hadland (2008); Charman et al. (2012) & Police reactiveness \\
$\begin{array}{l}\text { Gender-based dimensions } \\
\text { Mnyaka (2003); Nkealah (2011); Tsheola and Segage (2015); Tshishonga (2015) }\end{array}$ & Criminals or crime \\
$\begin{array}{l}\text { Safety and security, government's inability dimension } \\
\text { Crush and Willians (2003); Charman and Piper (2012); Leggett (2003); Nkealah (2011) }\end{array}$ & $\begin{array}{l}\text { Note: Please see the full reference list of this article, Ngcamu, B.S. \& Mantzaris, E., 2019, 'Xenophobic violence and criminality in the KwaZulu-Natal townships', The Journal for Transdisciplinary } \\
\text { Research in Southern Africa 15(1), a606. https://doi.org/10.4102/td.v15i1.606, for more information. }\end{array}$
\end{tabular}

Research in Southern Africa 15(1), a606. https://doi.org/10.4102/td.v15i1.606, for more information. 
society groups and community activists located in townships including Cato Crest, Bottlebrush, Dassenhoek and KwaNdengezi. Triangulation followed the findings in respect of the different questions used to interview the interviewees (Golafshani 2003:7). Researchers interviewed a total of 17 informants, a number in line with Charmaz (2006:113), Dworkin (2012:1319) and Marshall et al. (2013), who advocate smaller number of interviewees in qualitative research.

The face-to-face interviews were conducted at a prearranged venue decided upon by the respondents, mainly offices and informal settlements in and around Durban townships. The phenomenological interview (Bryman \& Bell 2014:4) was employed as the data collection method where the first-hand experiences of the respondents were shared. These were based on the extent of crime associated with the foreigners and evidence thereof; the perceptions regarding the ability of state organs to detect and prevent xenophobic violence or to alleviate its consequences; the extent to which the South African border situation contributes to the xenophobic violence in South Africa; and any other new realities and perspectives on the phenomenon.

The interviews were recorded using a voice recorder machine and transcribed verbatim. Researchers used Version 10 of the NVivo software that has been designed to facilitate common qualitative techniques for organising, analysing and sharing data. The software allows for qualitative inquiry beyond the coding, sorting and retrieval of data. It was also designed to integrate qualitative linking with coding, modelling and shaping (Wong 2008:15). For each interview conducted, themes and trends were developed and categorised in respect of the xenophobic violence of 2015.

The research findings of the study were trustworthy credibility was established whereby the research was conducted according to the principles of good practice and the interview transcripts and research findings were submitted to all informants in order to confirm their authenticity (Bryman \& Bell 2014:45; Lincoln \& Guba 1985).

\section{Research findings \\ The 'third force' and material conditions}

One of the key objectives of the study was to test and ascertain the truth in the theory of the existence and actions of a third force behind the xenophobic violence in the province of KwaZulu-Natal and the government's capability of detecting and reacting to such a catastrophe.

Monson (2012) elaborates on the reasons why the South African government refutes the very existence of xenophobic violence but rather considers it as workings of a so-called third force.

Almost all the representatives of the civil society groups who were interviewed refuted the existence of a third force as an explanation for the xenophobic violence.
As a community activist of many years declared:

'In all my life in the movement, I have come to believe that the only third force is the state and its agencies; they are the ones calling something they don't like a "third force".' (Community Activist, male, unemployed)

The mere fact that competition amongst African foreigners themselves leads to 'fights' and reciprocal attacks between different groups, as outlined in detail and evidenced by the leader of an NGO who assists refugees, is a clear negation of the existence of a third force. It was shown concretely that there is open and hidden cooperation amongst such groups operating with small local gangs, leading to looting of the 'opposition'.

The 'theory' is also negated by the 'selection' of nationalities that are perpetually targeted (Congolese, Zimbabweans, Malawians, Mozambicans, Ethiopians and Somalis). On the other hand, Pakistani, Chinese and Bangladeshi nationals have not been targeted, as they are not perceived to be 'competing with locals for access to resources'. Targeting people from poor countries, as presented by the interviews, supports numerous authors (Hall 2011; Perry 2001; Wolfe \& Copeland 1994) who claim that criminals target them because they are not valued in communities and are also marginalised.

A provincial government official indicated that the theory of the third force is negated by the material realities evident before and after the attacks, including competition such as access to resources; business and employment rivalry amongst national groups and South Africans; complete failure to regulate the registration of businesses; involvement of émigré communities in criminal activity, such as drug trafficking and trading in stolen goods; and the spreading of misinformation on social media platforms.

It was a police official who had worked on the problem associated with widespread criminal activity, mostly drugrelated as well as jealousy as key reasons. Such evidence coincides with empirical findings, pinpointing that violence is based more on the actions of thugs, and fuelled mainly by Somalian shopkeepers who are aligned to local gangsters and street committees (violent entrepreneurship) (Charman \& Pine 2012).

This concurs with the findings of a number of researchers (Bekker et al. 2008; Landau et al. 2005) who have described how such shady operators are working collaboratively with the state apparatus, including the police and Home Affairs officials.

As a provincial manager outlined, existing material conditions at the sites of xenophobic attacks point to the reality of competition for scarce resources; the influx of foreigners because of the border situation; the situation of corruption in the Home Affairs Department; competition at all levels; the private sector's preference for foreigners who are paid less and do not join trade unions; and the lack of 'serious intelligence services'. 
This is incongruous with numerous authors who claim that the xenophobic violence is triggered mostly by economic competition (Goddey 2017; Wimmer 1997) and job opportunities (Nyamnjoh 2006; Tshishonga 2015). Bekker et al.'s (2008) conclusion that government policies on border control and diplomatic relationships with other countries have exacerbated this violence is also supported.

Besides these existing conditions, there have also been specific cases, as in the case of Isipingo outside Durban, where attacks were rooted in the replacement of South Africans with foreigners in a factory, combined with popular dissatisfaction with service delivery. This analogy was corroborated by Bekker et al. (2008) that government's policy failure with regard to service delivery triggers xenophobia.

On the other hand, the assessment by Goddey (2017) and Tsheola, Ramoroka and Muzondi (2015), who argue that discrimination against foreign nationals is instigated and institutionalised by state security agents and leaders, has been negated. It has been reiterated time and again that people in the township know the realities, but still the government talk about a third force.

\section{The mechanisms for understanding, detecting, investigating and responding to xenophobia}

There was a general belief amongst the interviewees in the public service that the key weakness in fighting xenophobia has been the lack of coordination amongst the relevant state security clusters. This led to non-existent plans, whilst there is the knowledge that such attacks will continue. This is the result of the lack of a comprehensive risk assessment. In addition, there is no planning for services for the displaced foreign nationals, and there has been pressure by locals on state organs, complaining about foreigners and their behaviour. This leads to the reality that opportunists and criminal elements take advantage. Young people are in the forefront of the attacks.

The situation is exacerbated by the fact that young South Africans are jobless, whilst many of the foreigners have work permits and are married to South African women. Different key stakeholders have pointed out the government's reaction and inability to prepare for and respond to such violence. A community activist of many years indicated that the belief of the community is that government is not interested, and they only request the police after everything is over. The lack of intelligence collection and analysis is key, despite the fact that they may have been warned about the attacks and the involvement of foreigners in crime activities, whilst 'police do nothing'. They simply arrive after the looting of shops ends.

The police have no patrols, and some of them who stay in the area operate together with the crooks and criminals. They have no capacity to control the crowds. These sentiments are in agreement with the findings of different authors (Charman \& Piper 2012; Crush \& Williams 2003; Nkealah 2011) who have discovered that areas prone to xenophobic violence have over the years faced the problem of high crime levels. This is aggravated by the presence of the foreign nationals working in conjunction with the police.

It was revealed by two community activists in different areas that in both the 2008 and 2015 attacks, the police arrived late and took 300 foreigners to the police station 'to protect them'. However, by that time all the shops had been burnt and looted.

It is known in the townships that the South African Police Service (SAPS) have informers who are paid to 'spy' on certain categories of foreigners - Mozambicans, Malawians and a few Somalis.

However, there is evidence that Somalis are on good terms with the police because they give them cooldrinks and groceries in exchange for letting them operate freely. Another prominent civil society activist indicated that the police in many areas have been alerted that immigrants are responsible for crime, drugs, stealing and fraud and in some areas are the masterminds behind it all. The police do nothing, as they lack the mechanisms and know-how in terms of strategies to combat attackers. 'Real crime intelligence' does not exist or is ineffective. All this despite the fact that attacks are occurring during 'risk-reduction campaigns' run by the municipality and driven by community safety and liaison.

A lack of communication from the police at all levels leads to many problems, according to community activists, as there are no patrols detecting criminality; hence, people are not prepared to work with them. People report crime, but the police have no vehicles or fuel.

On the other hand, thousands of foreigners have fraudulent Republic of South Africa (RSA) IDs from crooked officials, and they are involved in criminal work throughout. These are the things the police know and allegedly do nothing about.

\section{Informal settlements, the 'rent problem', electricity and youth involvement}

It has been established that a serious bone of contention that leads to xenophobic attacks, especially in informal settlements, is the fact that 'landlords' there prefer to rent to foreigners, who can afford to pay, unlike locals. A shortage of housing and the aforementioned preference has led to sporadic attacks against foreigners in areas such as Ekupholeni and Bottlebrush near the predominantly Indian Chatsworth suburb. The selling of reconstruction and development programme (RDP) houses to foreigners also creates tension amongst locals. There have been specific areas where local gangsters operate with young, unemployed groups in order to control the 'lucrative' rent and housing market flourishing in and around Bottlebrush and Ekupholeni. They control the market and offer 'protection'. The housing and rent issue is directly related to the issue of gangsterism, youth and electricity theft in informal settlements. It is controlled by gangsters who 'specialise' in cable theft, 
burglaries and carjacking, assisted by youth who are trained in a variety of 'skills'. This takes place in most informal settlements, operating in gangs of 5,10 or 12 people at a time.

The trend that emerged in this study was that key instigators and participants in the xenophobic violence were young and unemployed black men. One civil society activist stated that the looting of foreigners' shops pulls people together, but the young people lead the crowds because they have their eyes on the ground and people in the township know what is happening and they do not hide things. The journalists come after things happen and they pretend they know everything. They are not interested in their lives; that's why they and the government talks about the third force.

Another civil society member indicated that on occasion groups of between 10 and 12 young people with branches, sticks and knives attacked Malawian and Zimbabwean drug dealers in the area and left them bleeding after stealing the 'merchandise' and everything they had, including their shoes.

This finding has been corroborated by Bekker et al. (2008), who believe that the poor young men see an opportunity to access resources as a result of the xenophobic violence by looting the businesses and properties belonging to these foreign nationals. This finding also concurs with the economic theory (Fungurai 2015; Soyombo 2008), which associates xenophobia with poverty and unemployment amongst youth.

\section{The 'border question'}

Different informants elaborated on the extent to which South African borders are contributing to the xenophobic violence in South Africa. A senior provincial politician who had visited the borders said that they were unguarded, enabling the free flow of immigrants and refugees from all neighbouring countries.

A key reason for this is weak budgets and insufficient (and on many occasions corrupt) guards, who, under the circumstances, are underpaid.

It was believed that the situation in the next few years will worsen, as things throughout Africa will not become better and most of Europe has closed its doors to refugees.

\section{Conclusion}

The article's empirical research both confirmed and rejected theories and empirical findings already produced on xenophobic violence in South Africa. It discovered that there is severe competition amongst African migrants, including groups from the same countries who compete between themselves, sometimes violently. The competition between foreign and local businesses also leads to violence, and it has been shown that both groups have created 'alliances' with both the police and unemployed youth groups in the perpetual struggle for dominance, both in business as well as in criminal endeavours.
The diversified group of interviewees, including provincial and local government representatives and community and NGO activists, believed that the third force claims have been driven mostly by the South African government, its agencies and the media, and the 'force' is just a cover-up for incompetence. Anew insight into the situation that provides a foundation for attacks is the material conditions in African townships and informal settlements - the never-ending existence of the 'housing or selling or renting' market, controlled by gangs who ally themselves occasionally and opportunistically with foreign traders and the police and use young people for their misdeeds. They have also influenced xenophobia in the Durban area.

There is a unanimous belief that the organisational weaknesses of the police both at strategic and tactical levels are instrumental in the perpetration of the attacks, as the force is lacking in detection, investigation, intelligence-driven and risk-reduction analysis and planning that would lead to effective implementation of strategies and tactics against violence. The well-known and admitted corruption in key departments such as Home Affairs and Correctional Services as well as municipalities exacerbates the existing problems created by the 'wide open borders, uncontrolled policy'.

Whichever direction the country takes in the next few years, unless key state institutions such as the SAPS, Home Affairs, municipalities and provinces operate in accordance with the existing laws and rules, the attacks and violence will continue. The enforcement of business laws or by-laws on illegal businesses mainly dominated by foreigners in the townships, the Department of Labour's failure to conduct audits on private organisations and other institutions that employ foreign nationals illegally, and an overhaul of the porous borders, as well as the relentless fight against crime and corruption in the state, the private sector and communities are the only way out from a social, economic, political and human disaster

\section{Acknowledgements}

Funding for this study was provided by the National Research Foundation (NRF) Thuthuka. Project research reference number: TTK160527166475.

\section{Competing interests}

The authors declare that they have no financial or personal relationships that may have inappropriately influenced them in writing this article.

\section{Authors' contribution}

B.S.N. and E.M. designed, collected and analysed the data. Both authors wrote the article.

\section{References}

Akinola, A.O., 2014, 'South Africa and the two faces of xenophobia: A critical reflection', Africa Peace \& Conflict Journal 7(1), 56-67.

Allport, G.W., 1961, Pattern and growth in personality, Prentice Hall, New York. 
Bekker, S., Eigelaar-Meets, I., Eva, G. \& Poole, C., 2008, 'Xenophobia and violence in South Africa: A desktop study of the trends and a scan of explanations offered', University of Stellenbosch.

Blumberg, B., Cooper, D.R. \& Schindler, P.S., 2005, Business Research Methods, McGrawHill, London.

Bryman, A. \& Bell, E., 2014, Research methodology: Business and management contexts, Oxford University Press Southern Africa, Cape Town.

Charman, A. \& Piper, L., 2012, 'Xenophobia, criminality and violent entrepreneurship: Violence against Somali shopkeepers in Delft South, Cape Town, South Africa', South African Review of Sociology 43(3), 81-105. https://doi.org/10.1080/21528 586.2012.727550

Charman, A., Petersen, L. \& Piper, L., 2012, 'From local survivalism to foreign entrepreneurship: The transformation of the spaza sector in Delft, Cape Town', Transformation: Critical Perspectives on Southern Africa 78(1), 47-73. https://doi. org/10.1353/trn.2012.0035

Charmaz, K., 1990, 'Discovering chronic illness: Using grounded theory', Social Science \& Medicine 30(11), 1161-1172. https://doi.org/10.1016/0277-9536(90)90256-R

Charmaz, K., 2006, Constructing grounded theory: A practical guide through qualitative research, Sage Publications, London.

Clark, J.D., 2011, 'Cash, schools, and immigrants: The effects of income and education on xenophobia in South Africa', Sigma: Journal of Political and International Studies 28(1), 4

Craig, K.M., 2002, 'Examining hate-motivated aggression: A review of the social psychological literature on hate crimes as a distinct form of aggression', Aggression and Violent Behavior 7(1), 85-101. https://doi.org/10.1016/S1359-1789(00)00039-2

Crowther, J. (ed.), 1995, Oxford advanced learner's dictionary for English: Internationa new students, Oxford University Press, London.

Crush, J. (ed.), 2008, The perfect storm: The realities of xenophobia in contemporary South Africa, Institute for Democracy in South Africa (Idasa), Cape Town.

Crush, J. \& Ramachandran, S., 2009, Xenophobia, international migration and human development (No. HDRP-2009-47), Human Development Report Office (HDRO), New York City, NY.

Desai, A., 2008, 'Xenophobia and refugees in the rainbow nation of human rights', African Sociological Review/Revue Africaine de Sociologie 12(2), 49-68.

Dodson, B., 2010, 'Locating xenophobia: Debate, discourse, and everyday experience in Cape Town, South Africa', Africa Today 56(3), 2-22. https://doi.org/10.2979/ aft.2010.56.3.2

Dodson, B. \& Oelofse, C., 2002, 'Shades of xenophobia: In-migrants and immigrants in Mizamoyethu, Cape Town', in J. Crush \& D. McDonald (eds.), Transnationalism and New African Immigration to South Africa, pp. 124-148, Southern African Migration Project, Cape Town.

Dworkin, S.L., 2012, 'Sample size policy for qualitative studies using in-depth interviews', Archives of Sexual Behaviour 41(6), 1319-1320.

Everatt, D., 2011, 'Xenophobia, state and society in South Africa, 2008-2010, Politikon: South African', Journal of Political Studies 38(1), 7-36. https://doi.org/10. 1080/02589346.2011.548662

Fungurai, P.N., 2015, Xenophobic attacks in South Africa - redefining apartheid, viewed 04 May 2015, from http://www.transconflict.com/about/

Goddey, W., 2017, 'Xenophobic activities and its impact on African peace and development' International Journal of Arts and Humanities(IJAH) 6(3), S/No 22: 41-50.

Golafshani, N., 2003, 'Understanding reliability and validity in qualitative research', The Qualitative Report 8(4), 597-606.

Hadland, A., 2008, Violence and xenophobia in South Africa: Developing consensus, moving to action. Human Sciences Research Council, Pretoria.

Hall, A., 2011, 'Migration and Thailand: Policy, perspectives and challenges', in J.W. Huguet \& A. Chamratrithirong (eds.), Thailand migration report 2011, pp. 85-93, International Organization for Migration, Thailand Office, Bangkok.

Hall, N., 2013, Hate crime, Routledge, London.

Harris, B., 2002, 'Xenophobia: A new pathology for a new South Africa', in D. Hook, \& G. Eagle (eds.), Psychopathology and Social Prejudice, pp. 169-184, University of Cape Town Press, Cape Town.

Hook, D. \& Eagle, G., 2002, 'Xenophobia: A new pathology for a new Africa?', Psychopathology and Social Prejudice, pp. 169-181, University of Cape Town Press, Cape Town.

HSRC, 2013, South African Social Attitudes Survey (SASAS), Pretoria, viewed 27 July 2016, from http://ecommons.hsrc.ac.za/handle/20.500.11910/5188; https:// www.ajol.info/index.php/ijah/article/viewFile/161116/150677

Khosa, R.M. \& Malitani, V., 2014, 'Challenges in operating micro-enterprises by African foreign entrepreneurs in Cape Town, South Africa', Mediterranean Journal of Social Sciences 5(10), 205-215. https://doi.org/10.5901/mjss.2014.v5n10p205

Landau, L.B., 2012, Exorcising the demons within: Xenophobia, violence, and statecraft in contemporary South Africa, Wits University Press, Johannesburg.

Landau, L.B. \& Jacobsen, K., 2004, 'Refugees in the New Johannesburg', Forced Migration Review 19(1), 44-46.

Landau, L.B., Ramjathan-Keogh, K. \& Singh, G., 2005, Xenophobia in South Africa and problems related to it, Forced Migration Studies Programme, University of the Witwatersrand, Johannesburg.

Leggett, T., 2003, Rainbow Tenement: Crime and policing in inner Johannesburg Institute for Security Studies. No.78, Pretoria.
Lincoln, Y.S. \& Guba, E.G., 1985, Naturalistic inquiry, Sage Publications, Beverly Hills.

Mamabolo, M.A., 2015, 'Drivers of community xenophobic attacks in South Africa: Poverty and unemployment', The Journal for Transdisciplinary Research in Southern Africa 11(4), 143-150. https://doi.org/10.4102/td.v11i4.49

Marshall, B., Cardon, P., Poddar, A. \& Fontenot, R., 2013, 'Does sample size matter in qualitative research? A review of qualitative interviews in IS research', Journal of Computer Information Systems 54(1), 11-22. https://doi.org/10.1080/08874417. 2013.11645667

McDonald, D.A. \& Jacobs, S., 2005, '(Re)writing xenophobia: Understanding press coverage of cross-border migration in Southern Africa', Journal of Contemporar African Studies 23(3), 295-325. https://doi.org/10.1080/02589000500274050

Mnyaka, M.M.N., 2003, Xenophobia as a response to foreigners in post-apartheid South Africa and post-exilic Israel: A comparative critique in the light of the gospel and ubuntu ethical principles, University of South Africa, Pretoria.

Monson, T., 2012, Making the law; breaking the law; taking the law into our own hands: Sovereignty and territorial control in three South African settlements, United Nations University Press with Wits University Press, Johannesburg.

Morris, A., 1998, “"Our fellow South Africans make our lives a living hell”: The lives of Congolese and Nigerians living in Johannesburg', Ethnic and Racial Studies 21, 6. https://doi.org/10.1080/01419879808565655

Mothibi, K.A., Roelofse, C.J. \& Tshivhase, T., 2015, 'Xenophobic attacks on foreign shop owners and street vendors in Louis Trichardt Central Business District, Limpopo Province', The Journal for Transdisciplinary Research in Southern Africa 11(4), 151-162.

Neocosmos, M., 2010, From foreign natives to native foreigners. Explaining xenophobia in post-apartheid South Africa: Citizenship and nationalism, identity and politics, Council for the Development of Social Science Research in Africa (CODESRIA), Senegal.

Neocosmos, M., 2011, 'Transition, human rights and violence: Rethinking a libera political relationship in the African neo-colony', Interface 3(2), 359-399.

Nkealah, N., 2011, 'Commodifying the female body: Xenophobic violence in South Africa', Africa Development 36(2), 123-136.

Nyamnjoh, F.B., 2006, Insiders and outsiders: Citizenship and xenophobia in contemporary Southern Africa, Zed Books, New York.

Oucho, J.O., 2006, 'Cross-border migration and regional initiatives in managing migration in Southern Africa', in Migration in South and Southern Africa: Dynamics and determinants, Human Sciences Research Council (HSRC) Press, Pretoria.

Perry, B., 2001, In the name of hate: Understanding hate crimes, Routledge, New York.

Ramphele, M., 2008, 'Xenophobia crisis should jolt us from apathy', Cape Times, 23 May, 2008, p. 9.

Ruedin, D., 2018, Not everyone is xenophobic in South Africa, Open Science Framework $1(1), 1-4$.

Saunders, M., Lewis, P. \& Thornhill, A., 2007, 'Formulating the research design', in M. Saunders, P. Lewis \& A. Thornhill (eds.), Research Methods for Business M. Saunders, P. Lewis \& A. Thornhill (eds.), Researc
Students (pp. 130-161), Pearson Education, London.

Sheffield, C., 1995, 'Hate Violence', in P. Rothenberg (ed.), Race, class and gender in the United States, 3rd edn., pp. 432-441, St. Martin's, New York, NY.

Shisana, H., 2008, We need to address Xenophobia, viewed 02 February 2015, from http/www.xenophobia.com/southafrica/phpon

Soyombo, O., 2008, 'Xenophobia in contemporary society: A sociological analysis', IFE Psychologia: An International Journal 16(2), 85-104. https://doi.org/10.4314/ ifep.v16i3.23779

Steenkamp, C., 2009, 'Xenophobia in South Africa: What does it say about trust?', The Round Table 98(403), 439-447. https://doi.org/10.1080/00358530903017949

Steinberg, D.I., 2006. Turmoil in Burma: Contested legitimacies in Myanmar, Signature Books, Salt Lake City, UT.

Steinberg, J., 2010, 'Mother City offers little in way of succour to foreigners', Sunday Times, 7 November, 2010, n.p.

Tafira, K., 2011, 'Is xenophobia racism?', Anthropology Southern Africa 34(3-4), 114-121. https://doi.org/10.1080/23323256.2011.11500015

Tseola, J., Ramoroka, T. \& Muzondi, L., 2015, 'Xenophobic societal attitudes in a "new" South Africanism: Governance of public perceptions, national identities and citizenship', The Journal for Transdisciplinary Research in Southern Africa 11(4), December 2015, Special edition, 232-246.

Tshishonga, N., 2015, 'The impact of xenophobia-Afrophobia on the informal economy in Durban CBD, South Africa', The Journal for Transdisciplinary Research in Southern Africa 11(4), 163-179. https://doi.org/10.4102/td.v11i4.52

Tsheola, J. \& Segage, M., 2015, 'Governance, "sovereignty-state-territory triad", human population migration and xenophobia in (South) Africa', The Journal for Transdisciplinary Research in Southern Africa 11(4), 30-46.

Tshitereke, C., 1999, 'Xenophobia and relative deprivation', Crossings 3(2), 4-5.

Wimmer, A., 1997, 'Explaining xenophobia and racism: A critical review of current research approaches', Ethnic and Racial Studies 20(1), 17-41. https://doi.org/10. 1080/01419870.1997.9993946

Wolfe, L. \& Copeland, L., 1994, Violence against women as bias-motivated hate crime Defining the issues in the USA, United States Agency for International Development (USAID), New York, NY.

Wong, L.P., 2008, 'Data analysis in qualitative research: A brief guide to using NVivo', Malaysian Family Physician 3(1), 7 